\title{
Applications of Factorial Analysis in the Study of Risk Factors and their Chemical Influence for Erosive Dental Wear
}

\author{
ADINA-MONICA CHIRIAC ${ }^{1}$, VERONICA MERCUT ${ }^{1 *}$, DRAGOS ALEXANDRU ${ }^{1}$, SANDA-MIHAELA POPESCU ${ }^{1}$, RAZVAN MERCUT ${ }^{1}$, \\ FLORIN-DAN POPESCU ${ }^{2}$, DELIA LUCHIANCENCO ${ }^{1}$, IONUT RESCEANU ${ }^{3}$ \\ 'University of Medicine and Pharmacy Craiova, Faculty of Medicine, 2-4 Petru Rares Str., 200349, Craiova, Romania \\ ${ }^{2}$ Carol Davila University of Medicine and Pharmacy, 37 Dionisie Lupu Str., 020021,Bucharest, Romania \\ 3University of Craiova, 13 A.I. Cuza Str., 200585, Craiova, Romania
}

\begin{abstract}
Dental wear is an irreversible loss of dental hard tissues under the action of physical and chemical factors that may come from the external or internal environment of the body. Dental wear is the consequence of three mechanisms: biocorrosion, friction and stress. The purpose of the study was to determine the impact of risk factors on the severity of erosive dental wear in children using factorial analysis. In this context, we used data from a statistical survey conducted between 2017-2018 on 456 rural and urban children aged 6 to 11 years, where dental wear was analyzed according to a series of diet-related factors, oral hygiene and behavioral patterns (bruxism). The major impact was caused by energy drinks, yoghurt and carbonated beverages. Through the associations resulting from the factorial analysis, the mechanisms involved in the erosive dental wear were also highlighted, and the main was biocorrosion, followed by friction and stress.
\end{abstract}

Keywords: factorial analysis, erosive dental wear, variables, factors

Dental wear is an irreversible loss of tooth hard tissues under the action of physical and chemical factors originated from the external or internal environment of the body [1]. Erosive dental wear is the consequence of three mechanisms: biocorrosion, friction and stress [2-4]. Nowadays, it is widely accepted that several mechanisms are involved in the production of each clinical form of dental wear [4-7]. Erosive dental wear has been receiving special attention as a result of an increase in its prevalence both in children and young adults as well as in adults due to a change in lifestyle [8]. Thus, a series of epidemiological studies showed prevalence between $30 \%[9,10]$ and $97.6 \%$ [11].

In children and youngsters, the most common form of dental wear is dental erosion, especially on deciduous teeth [12]. A series of studies analyzed dental erosion on deciduous and permanent teeth $[13,14]$. Dental erosion begins with a demineralization of enamel surfaces that progress to an extensive loss of hard tissue when the contact with acids continues [15, 16]. Several studies have been conducted over time to highlight the effects of various substances contained in food, beverages or medicines in dental erosion [17-21], most of them on permanent teeth.

The deciduous teeth enamel is less mineralized, with a higher carbonate content and organic matrix than permanent teeth enamel [22]. These differences may justify a higher predisposition to dental wear for deciduous teeth than for permanent teeth. If excessive occlusal forces, such as bruxism, are associated with this structural predisposition, then the susceptibility of deciduous teeth to dental wear is very high. A number of studies have highlighted the fact that children who have experienced deciduous teeth erosions have been at increased risk for permanent teeth erosions $[23,24]$.

The risk factors involved in erosive dental wear are numerous, being grouped into two categories: endogenous (with origins inside the body, such as gastric acid reflux or bruxism) and exogenous (with origins outside the body, such as acids in food or dental brushing) [7]. Correlations between risk factors and dental erosion have been studied through several methods, such as linear regression analysis $[25,26]$, and multivariate logistic regression analysis model [27-29].

In this study, we decided to use the method of factorial analysis to investigate the relationships between potential risk variables and erosive dental wear. The purpose of the study was to determine the impact of risk factors on the severity of dental erosion in children using factorial analysis.

\section{Experimental part}

For this study, the method of factorial analysis was used, starting with the data of a statistical survey carried out between 2017 and 2018 on 456 children from rural and urban areas aged between 6 and 11 years [30], where erosive dental wear was analyzed according to a number of factors related to diet, oral hygiene and a series of behavioral habits (e.g. bruxism). The study was approved by the Ethics Committee of the University of Medicine and Pharmacy Craiova.

The statistical data and database created in the Microsoft Excel program obtained from the clinical-statistical study were re-analyzed. First, the recorded variables were grouped to observe whether they are present at the same time with similar intensity, thus constituting factors that act in the direction of the evolution of dental wear. For this purpose, factorial analysis was used, a statistical method used to describe the variability between the directly observed parameters recorded in the data collection stage, among which there are multiple correlations, through a potentially smaller number of directly unobserved variables. Independent variables discovered by factorial analysis are called factors. Factorial analysis was performed with the XLSAT software package (Addinsoft SaRL, Paris, France). After grouping the variables, the correlations between the investigated variables and the dental wear score, calculated as the sum of the BEWE grades accorded to each tooth affected by dental wear were established. 
Depending on the intensity of the correlation of variables within each factor, the action of that factor was defined in terms of dental wear as being more or less aggressive. In order to evaluate the relationship between recorded variables and wear scores, the Pearson correlation coefficients $(r)$ were calculated. For the present study, the variables with the $P$ value calculated for the Pearson correlation coefficient below the significance of 0.05 were highlighted.

\section{Results and discussions}

The prevalence of dental erosion was $32.46 \%$, with 148 children identified as having erosive dental wear. Most children with dental wear had a wear score in the range of $5-14$, showing a moderate severity of erosive wear injuries (fig. 1).

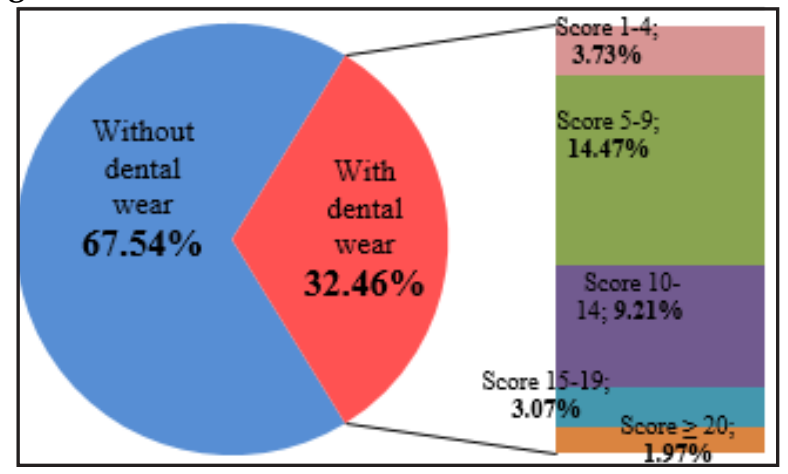

Fig.1. Dental wear score in the study lot with risk grades adapted by Bartlett 2008

In order to observe the magnitude of the dental wear phenomena, it was conducted a descriptive analysis of the variables measuring this fact (table 1 ). Wear ranged from 2 to 34 had an average of 7 affected teeth.

In this study, 40 variables (risk indicators), possibly involved in dental erosion, were analyzed. Because their individual impact was not statistically significant for the evolution of dental wear, the variables were grouped using factorial analysis, the frequency of ingestion of certain beverages / food, oral hygiene or frequency of bruxism episodes / debut of bruxism. These variables described eating habits, parafunctions and oral hygiene habits considered as independent risk factors that appeared to be associated with several study participants in this study. By factorial analysis, the above-described statistical method, 9 factors (variable patterns) were obtained, grouping the individual studied variables, defined as F1 to F9 (tables 2-10).

The number of factors was chosen to be equal to the number of values (eigenvalue) greater than 1 (Kaiser Rule). This rule is often used in factorial analysis as well as in

Table 1

DESCRIPTIVE ANALYSIS OF EROSIVE DENTAL WEAR IN THE STUDY GROUP

\begin{tabular}{|l|c|c|c|}
\hline Statistic & $\begin{array}{c}\text { Dental wear } \\
\text { score }\end{array}$ & $\begin{array}{c}\text { No. of teeth with } \\
\text { dental wear }\end{array}$ & $\begin{array}{c}\text { Medium } \\
\text { wear }\end{array}$ \\
\hline $\begin{array}{l}\text { No. of } \\
\text { observations }\end{array}$ & 148 & 148 & 148 \\
\hline Mean & 9.83 & 7.18 & 1.36 \\
\hline $\begin{array}{l}\text { Standard } \\
\text { deviation }\end{array}$ & 5.45 & 3.22 & 0.32 \\
\hline Minimum & 2 & 2 & 1.00 \\
\hline lst Quartile & 6 & 5 & 1.00 \\
\hline Median & 9 & 7 & 1.33 \\
\hline 3rd Quartile & 12 & 9 & 1.57 \\
\hline Maximum & 34 & 20 & 2.33 \\
\hline
\end{tabular}

Table 2

VARIABLES GROUPED IN FACTOR 1 (F1)

\begin{tabular}{|l|l|}
\hline Name of variables (FC - frequency of consumption) & Fl \\
\hline Tea / Herbal drinks - FC & 0.7176 \\
\hline Lemonade - FC & 0.7176 \\
\hline Tea / Herbal drinks & 0.7171 \\
\hline Lemonade & 0.7171 \\
\hline Natural fruit juice / pasted fruits - FC & 0.7013 \\
\hline Vitamin C tablets & 0.7008 \\
\hline Natural fruit juice / pasted fruits & 0.7008 \\
\hline Carbonated beverages - FC & 0.6338 \\
\hline Yoghurt & 0.6317 \\
\hline Fruit juice from commerce - FC & 0.6113 \\
\hline Grapes & 0.6113 \\
\hline Carbonated beverages & 0.5650 \\
\hline Fruit juice from commerce & 0.5493 \\
\hline Soup & 0.5349 \\
\hline Moment of dental brushing & 0.5079 \\
\hline
\end{tabular}

Table 3

VARIABLES GROUPED IN FACTOR 2 (F2)

\begin{tabular}{|l|l|}
\hline Name of variables (FC - frequency of consumption) & F2 \\
\hline Grapefruit & 0.9071 \\
\hline Lemon & 0.9071 \\
\hline Fruit yoghurt & 0.9071 \\
\hline Olives & 0.9046 \\
\hline Mayonnaise & 0.9043 \\
\hline Salads & 0.8883 \\
\hline Ketchup & 0.8744 \\
\hline
\end{tabular}

Table 4

VARIABLES GROUPED IN FACTOR 3 (F3)

\begin{tabular}{|l|l|}
\hline Name of variables (FC - frequency of consumption) & F3 \\
\hline Drinks from baby bottles & -0.9370 \\
\hline Stop drinking from baby bottle during nighttime & -0.8742 \\
\hline Drinking from baby bottles - FC & -0.8741 \\
\hline Drinking from baby bottle during nighttime & -0.8571 \\
\hline Iron tablets & -0.8137 \\
\hline Water & -0.7518 \\
\hline Stop drinking from baby bottle & -0.7322 \\
\hline Tea in baby bottle & -0.6829 \\
\hline Infant feeding & -0.5173 \\
\hline
\end{tabular}

Table 5

VARIABLES GROUPED IN FACTOR 4 (F4)

\begin{tabular}{|l|l|}
\hline Name of variables (FC - frequency of consumption) & F4 \\
\hline Fruit juice from commerce - FC & -0.5921 \\
\hline Grapes & -0.5921 \\
\hline Carbonated beverages - FC & -0.5885 \\
\hline Yoghurt & -0.5879 \\
\hline Moment of dental brushing & -0.5285 \\
\hline Fruit juice from commerce & -0.5107 \\
\hline Carbonated beverages & -0.5053 \\
\hline
\end{tabular}

Table 6

VARIABLES GROUPED IN FACTOR 5 (F5)

\begin{tabular}{|l|l|}
\hline Name of variables (FC - frequency of consumption) & F5 \\
\hline Dairy products - FC & -0.8538 \\
\hline Apples & -0.8538 \\
\hline Pickles & -0.8538 \\
\hline Dairy products & -0.7715 \\
\hline Energy drinks -FC & -0.6926 \\
\hline Energy drinks & -0.6611 \\
\hline
\end{tabular}

Table 7

VARIABLES GROUPED IN FACTOR 6 (F6)

\begin{tabular}{|l|l|}
\hline Name of variables (FC - frequency of consumption) & F6 \\
\hline Fruit syrup & 0.6569 \\
\hline Fruit syrup - FC & 0.5851 \\
\hline
\end{tabular}

Table 8

VARIABLES GROUPED IN FACTOR 7 (F7)

\begin{tabular}{|l|l|}
\hline Name of variables (FC - frequency of consumption) & F7 \\
\hline Bruxism & 0.7776 \\
\hline Debut of bruxiom (years) & 0.7183 \\
\hline Carbonated water - FC & 0.5480 \\
\hline Carbonated water & 0.5395 \\
\hline
\end{tabular}


Table 9

VARIABLES GROUPED IN FACTOR 8 (F8)

\begin{tabular}{|c|c|}
\hline Name of variables (FC - frequency of consumption) & F8 \\
\hline Carbonated water - FC & 0.5799 \\
\hline Carbonated water & 0.5794 \\
\hline \multicolumn{2}{|l|}{$\begin{array}{c}\text { Table } 10 \\
\text { VARIABLES GROUPED IN FACTOR } 9 \text { (F9) }\end{array}$} \\
\hline Name of variables (FC - frequency of consumption) & F9 \\
\hline Fruit syrup & 0.6144 \\
\hline Fruit syrup - FC & 0.5595 \\
\hline
\end{tabular}

Principal Component Analysis (PCA). There are several explanations for using this rule, the simplest being that because a value itself includes variability explained by a factor, it makes no sense to add a factor that explains less than the variance contained in a single variable. The cumulation of the top 9 factors with an influence greater than $1 \%$ of variability explains a total of over $76 \%$ of the data variation (table 11).

Table 11

THE IMPORTANCE OF THE FACTORS IN EXPLAINING THE VARIATION OF THE STUDIED VARIABLES

\begin{tabular}{|c|c|c|c|c|c|c|c|c|c|c|}
\hline & Fl & $F_{2}$ & F3 & F4 & F5 & F6 & F7 & F8 & F9 & F10 \\
\hline Eig & 7.66 & 7.05 & 6.32 & 5.25 & 4.56 & 2.00 & 1.87 & 1.74 & 1.42 & 0.92 \\
\hline $\begin{array}{c}\text { Variabili } \\
(\%)\end{array}$ & $\begin{array}{c}15.0 \\
3\end{array}$ & $\begin{array}{c}13.8 \\
2 \\
\end{array}$ & $\begin{array}{c}12.3 \\
8\end{array}$ & $\begin{array}{c}10.2 \\
9 \\
\end{array}$ & 8.95 & 3.93 & 3.67 & 3.41 & 2.78 & 1.81 \\
\hline $\begin{array}{c}\text { Cumulative } \\
(\%)\end{array}$ & $\begin{array}{c}15.0 \\
3\end{array}$ & $\begin{array}{c}28.8 \\
5\end{array}$ & \begin{tabular}{|c|}
41.2 \\
3
\end{tabular} & \begin{tabular}{|c|}
51.5 \\
2
\end{tabular} & $\begin{array}{c}60.4 \\
7\end{array}$ & $\begin{array}{c}64.4 \\
0\end{array}$ & $\begin{array}{c}68.0 \\
6\end{array}$ & $\begin{array}{c}71.4 \\
8\end{array}$ & $\begin{array}{c}74.2 \\
6\end{array}$ & $\begin{array}{c}76.0 \\
6\end{array}$ \\
\hline
\end{tabular}

Because F6 and F9 factors correlate with the same variables and the variables correlated with the F1, F4, F7 and F8 factors, partially overlap, F4, F8 and F9 factors were removed from the final predictive model of erosive dental wear. Since F1 factor was related to variables referring to consumption of highly acidic food, those associated with F2 factor referred to moderately acidic food and those associated with $\mathrm{F} 3$ and $\mathrm{F} 7$ factors referred to eating habits of mechanical nature, F5 factor to the consumption of strong acidic food and F6 factor referred to the use of low acidic syrups [21, 31].

Finally, the impact of the grouped variables into the identified factors on the severity of erosive dental wear was analyzed. After the analysis of the correlations between dental wear scores, calculated as the sum of the BEWE wear scores of all the affected teeth and the recorded variables, resulted that the variables associated with $F 5$ and F1 factors were those with the highest correlation coefficients (table 12). F2 factor associated variables showed neglectible correlation coefficients, probably due to their rare consumption among children (table 12).

The relation between the initial variables and the factors considered important (F1, F2, F5) is represented in the figures below (fig. 2a, fig. 2b). These graphs showed how the variables were grouped according to the theoretical identified factors. For example, consumption of lemonade, natural fruit juice, herbal drinks or tea was strongly associated with F1 factor and virtually not associated with F2 factor; consumption of carbonated beverages, commercial fruitjuices, yoghurt and soup were moderately (directly proportional) associated with F1 factor and reversely proportional to F2 factor, while consumption of ketchup, salads, fruits, olives, mayonnaise was directly proportional to $\mathrm{F} 2$ factor and was weaker, directly proportional to F1 factor (fig. 2a). Children who consumed ketchup, salads, olives or mayonnaise have been found to consume fewer soups, fruit juice from commerce,
Table 12

THE STATISTICALLY SIGNIFICANT CORRELATION COEF-FICIENTS CALCULATED BETWEEN THE VARIABLES WHOSE INFLUENCE WAS ANALYZED AND THE VARIABLES MEASURING THE EROSIVE DENTAL WEAR (NUMBER OF AFFECTED DENTAL UNITS, WEAR SCORE, RISK CATEGORIES, PRESENCE OF DENTAL WEAR)

\begin{tabular}{|c|c|c|c|c|}
\hline $\begin{array}{l}\text { Variables } \\
\text { PC - frequency of } \\
\text { consumption }\end{array}$ & $\begin{array}{l}\text { No. of } \\
\text { units }\end{array}$ & $\begin{array}{l}\text { Dental } \\
\text { wear } \\
\text { score }\end{array}$ & $\begin{array}{l}\text { Dental } \\
\text { wear } \\
\text { score - } \\
\text { classes }\end{array}$ & $\begin{array}{l}\text { Dental } \\
\text { Wear }\end{array}$ \\
\hline Euergy drinks - FC (F5) & 0.3416 & 0.3046 & 0.3477 & 0.4203 \\
\hline Evergy drinks (F⿹) & 0.3273 & 0.3029 & 0.3433 & 0.3898 \\
\hline Yoghurt (F1) & 0.2769 & 0.2694 & 0.2694 & 0.2707 \\
\hline $\begin{array}{l}\text { Carbonated beverages - FC } \\
\text { (F1) }\end{array}$ & 0.2757 & 0.2683 & 0.2682 & 0.2693 \\
\hline Changing toothbrush & 0.2531 & 0.2463 & 0.2494 & 0.2259 \\
\hline Dairy products - FC (F5) & 0.2171 & 0.2140 & 0.2275 & 0.2652 \\
\hline Apples (F5) & 0.2171 & 0.2140 & 0.2275 & 0.2652 \\
\hline Pickles (F5) & 0.2171 & 0.2140 & 0.2275 & 0.2652 \\
\hline Dairy products (F⿹) & 0.2126 & 0.2108 & 0.2331 & 0.2555 \\
\hline Soup (FI) & 0.2244 & 0.2089 & 0.2100 & 0.2303 \\
\hline Carbonated beverages (FI) & 0.2186 & 0.2047 & 0.2144 & 0.2122 \\
\hline $\begin{array}{l}\text { Fruit juice from commerce - } \\
\text { FC (F1) }\end{array}$ & 0.2034 & 0.1940 & 0.1911 & 0.1953 \\
\hline Grapes (FI) & 0.2034 & 0.1940 & 0.1911 & 0.1953 \\
\hline Frequency of dental brushing & 0.1842 & 0.1729 & 0.1742 & 0.1778 \\
\hline Fruit syrup - FC (F6) & 0.1824 & 0.1723 & 0.1727 & 0.1645 \\
\hline $\begin{array}{l}\text { Moment of dental brushing } \\
\text { (F1) }\end{array}$ & 0.1648 & 0.1578 & 0.1520 & 0.1242 \\
\hline Tea Herbal dinks - FC (F1) & 0.1643 & 0.1503 & 0.1774 & 0.1804 \\
\hline Lemonade -FC (FI) & 0.1643 & 0.1503 & 0.1774 & 0.1804 \\
\hline $\begin{array}{l}\text { Fruit juice from commerce } \\
\text { (F1) }\end{array}$ & 0.1474 & 0.1374 & 0.1414 & 0.1309 \\
\hline $\begin{array}{l}\text { Natural fruit juice / Pasted } \\
\text { fruits - FC (F1) }\end{array}$ & 0.1425 & 0.1287 & 0.1511 & 0.1567 \\
\hline Bruxism (F7) & 0.1388 & 0.1220 & 0.1256 & 0.1518 \\
\hline $\begin{array}{l}\text { Oranges (doesn't appear in the } \\
\text { variables associations) }\end{array}$ & 0.1253 & 0.1212 & 0.1321 & 0.1451 \\
\hline Carbonated water - FC (F7) & 0.1455 & 0.1145 & 0.1285 & 0.1443 \\
\hline $\begin{array}{l}\text { Fruit juice (doesn't appear in } \\
\text { the variables associations) }\end{array}$ & 0.0997 & 0.1057 & 0.1288 & 0.0994 \\
\hline $\begin{array}{l}\text { Bottles (doesn't appear in the } \\
\text { variables associations) }\end{array}$ & 0.0911 & 0.0882 & 0.0740 & 0.0769 \\
\hline Fruit syrup (F6) & 0.0842 & 0.0867 & 0.0818 & 0.0751 \\
\hline $\begin{array}{l}\text { Hot chocolate - FC (doesn't } \\
\text { appear in the variables } \\
\text { associations) }\end{array}$ & 0.0670 & 0.0821 & 0.0663 & 0.0521 \\
\hline Tea/ Plant drinks (F1) & 0.0759 & 0.0734 & 0.0985 & 0.0951 \\
\hline Lemonade (FI) & 0.0759 & 0.0734 & 0.0985 & 0.0951 \\
\hline $\begin{array}{l}\text { Stop drinking from baby } \\
\text { bottles (F3) }\end{array}$ & 0.0951 & 0.0715 & 0.0968 & 0.1447 \\
\hline
\end{tabular}

carbonated drinks, etc. - the variables found in the fourth quadrille of the graph presented in Figure no. 2a. Among the variables associated with F1 and F5 factors, there was a higher dissociation than between $\mathrm{F} 1$ and F2 factors, the variables strongly correlated with F1 factor having a directly proportional weak correlation with F5 factor and the variables strongly correlated (reversely proportional) with F5 factor (consumption of energy drinks, apples, pickles, dairy products) having directly weak correlations with F1 factor (fig. 2b). Because variables associated with F1 and F5 factors were strongly correlated with dental wear and were less related between themselves, F1 and F5 factors 


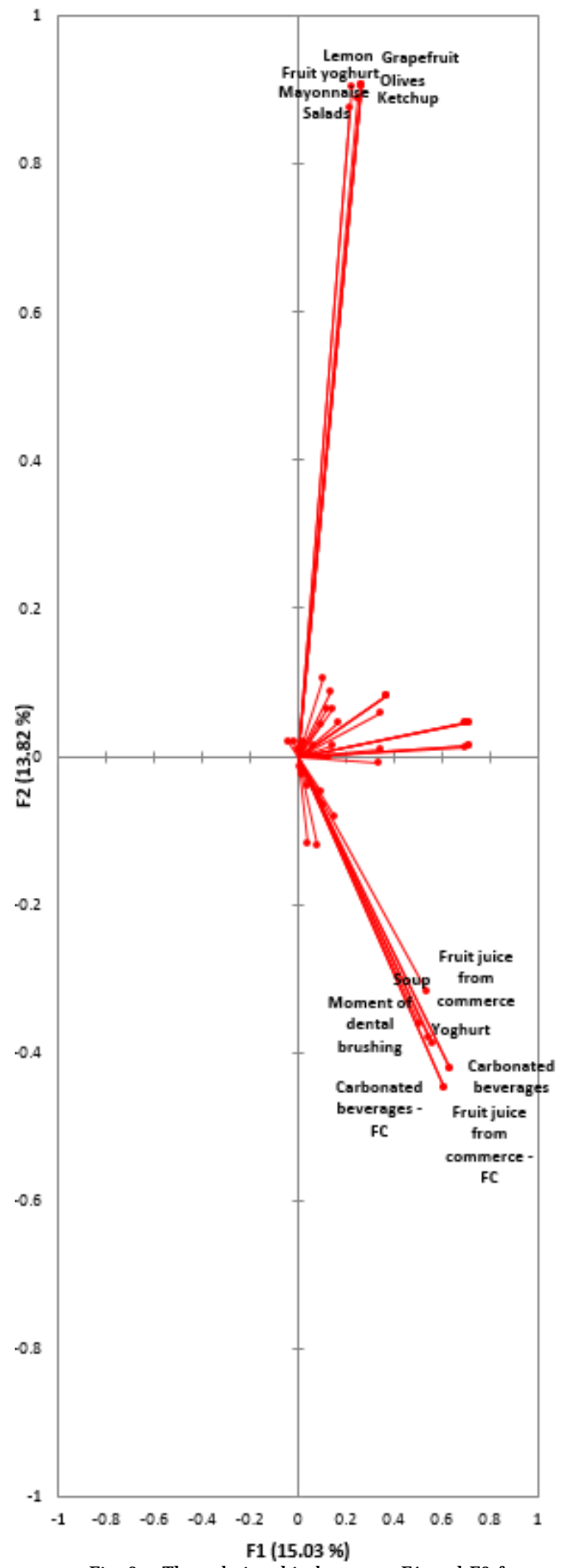

Fig. $2 a$ The relationship between F1 and F2 factors

were independent and were the main causes of dental wear investigated in this study.

This study used factorial analysis, a method with origins in psychometrics, and with applications in behavioral sciences, social sciences, marketing, product management and other domains dealing with data sets where large number of observed variables may reflect a small number of hidden latent variables [32]. Factorial analysis was used to study the patterns of relationships between several variables directly observed to highlight

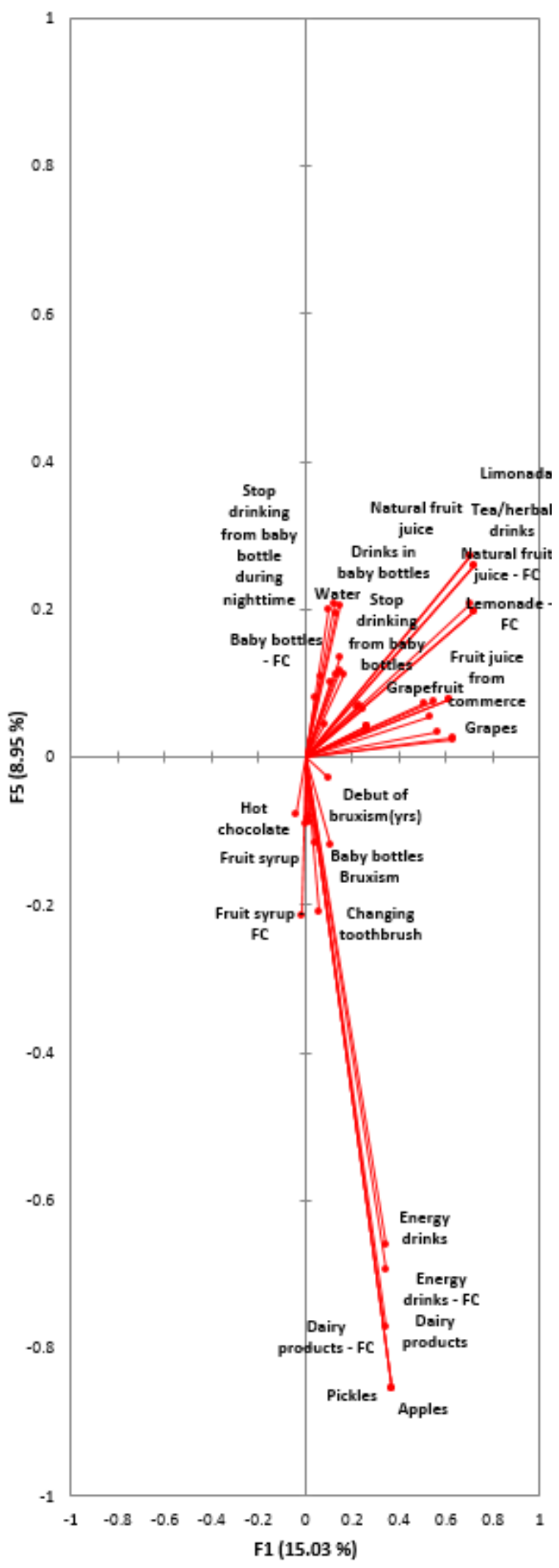

Fig. $2 \mathrm{~b}$ The relationship between $\mathrm{F} 1$ and $\mathrm{F} 5$ factors

aspects of the relationships between them, a common substrate, even if these new independent variables were not directly measured. Thus, the answers obtained from the factorial analysis are obviously more theoretical / hypothetical compared to situations when independent variables are directly observed [33].

The study highlighted the fact that there was a number of risk factors involved in the etiology of dental wear (erosion) and also that some associations between these 
factors had a greater potential in etiology of erosive dental wear. Risk factors assessed as variables act through the three mechanisms of dental wear: acidic food, acidic drinks and frequency of their consumption - biocorrosion; dental brushing and oral hygiene - friction and bruxism stress.

In terms of biocorrosion, the study highlighted the highest erosive potential for energy drinks by frequency of consumption and quantity (F5), yoghurt and carbonated drinks by frequency of consumption and quantity (F1). A number of other factors have been highlighted as having increased erosive potential: apples, pickles, commercial fruit juices through consumption frequency. A moderate influence in etiology of dental erosion had fruit syrup, herbal teas, lemonades, citrus, all especially through the frequency of consumption. Other studies have shown a positive association between diet and dental wear [26, 30, 34, 35]. According to Lussi [34], knowledge of the erosive potential of different types of beverages and food is necessary for the general dentist to determine the patient's risk of developing dental wear. The various erosive potentials of approximately 50 types of food and beverages could be found in a reference article on erosive dental wear [35]. Diet and lifestyle are an important component of exogenous factors involved in dental wear. Many studies on child populations have shown a direct correlation between the consumption of carbonated beverages, fruit juices and dental wear in children [25,36,37], excessive consumption of acidic beverages and food being the most important extrinsic factor contributing to dental wear [38]. The recent dramatic increase in the consumption of acidic fruitjuices, fruit drinks and carbonated beverages is now considered the most important cause of erosive dental wear observed in children and adolescents [39]. In conclusion, one of the potential common causes of erosive dental wear is the intake of carbonated beverages [40], the frequency of their consumption (F1 factor) being associated with dental erosion [41, 42]. Similarly, administration of vitamin C supplements (F1 factor) was associated with erosive dental wear similar to other published studies [43]. Consumption of soft drinks and energy drinks by school children was related to age and gender [44, 45]. Significant positive associations between the consumption of energy drinks suggested that there was a subgroup of school children with a cumulative high intake of these potentially erosive beverages, a subgroup characterized by a low level of education. Beverages, food and medications commonly consumed by children from the study group could have caused dental wear, mainly associated with acidic $\mathrm{pH}$, testable levels of acids and calcium concentration in the solution [46].

The role of friction in this study was represented by dental brushing, referring to the time of use of the toothbrush, the brushing frequency and the time when dental brushing was performed (after the consumption of acidic food or not). According to factorial analysis, the association between the consumption of some food or acidic drinks and the time of performing the dental brushing had a greater impact on dental erosion but, separately analyzed, the consumption of food and acidic beverages prevailed. In the literature, there was much controversy about the role of dental brushing in dental erosion [10]. . ing Zhang [47] show ed that if dental brushing was performed once a day or less and lasted less than 2 minutes, there had been an increased risk of erosive dental wear. Instead, a previous study confirmed that participants who brushed their teeth twice or more times a day had a higher frequency of dental wear [48]. Dental wear was associated with brushing frequency and the use of various local cleansing agents. Multiple regression analysis showed that age, brushing, brushing after breakfast, gave a statistically significant prediction of dental wear prediction $(P<0.05)$.

Stress was represented in this study by bruxism. According to factorial analysis, bruxism had a lower percentage in erosive dental erosion compared to acidic food and dental brushing. The incidence of bruxism in F7 factor showed the low regression of this variable and the fact that it could not have produced dental erosion without an association with other factors. Lobbezoo [49], suggested that bruxism and eating habits were involved in the etiology of dental wear in mixed dentition. It should be highlightened that, according to this study, the presence of dental wear as a pathognomonic symptom of bruxism in mixed dentition is not sustained. However, the influence of various inter-maxillary relationships in mixed dentition and the analysis of jaw movements during craniofacial growth should be considered in further studies for this topic [50]. The results of a study [51] demonstrated that there was a significant association between bruxism and the occurrence of 4 clinical signs (anterior or posterior dental wear, abrasion and occlusal erosion). It was suggested that signs of dental wear could differentiate self-reported bruxomania from bruxism [51]. Significant correlations were also found between reports of bruxism, tooth wear and muscle symptoms observed in the morning time, suggesting that these variables could be observed simultaneously [52].

Factorial analysis allowed the identification of pathogenically risk factor associations with a greater erosive potential in erosive dental wear that could be found in the behavioral habits of the children included in the study. Thus, the association of variables within F1 or F5 factor caused the greatest risk for erosive dental wear. These tw o factors included the association of energy drinks with apples, pickles, dairy products or carbonated beverages, or the association of some strongly acidic $\mathrm{pH}$ variables with other more acidic $\mathrm{pH}$ variables.

From what we know so far, no other research groups used factorial analysis to study dental wear risk factors, but this method has been used to determine the impact of eating habits on obesity [53]. However, several studies showed associations of dietary habits and erosive dental wear and associations between dental wear mechanisms (biocorrosion, stress and friction) [4, 54, 55, 56,57-66]. Assessment of dental wear in a multi-variable study, including other etiological factors notevaluated in this study (e.g. dental occlusion, oral hygiene techniques), could lead to a more accurate determination of the etiology of dental wear. This framew ork should be supported by prospective longitudinal studies.

\section{Conclusions}

Factorial analysis allowed the variables studied (risk factors) to be grouped into nine factors based on their types of associations. The most important for erosive wear were F5, F1, F7 and F6 factors, respecting this order. The variables associated with F5 and F1 factors were those with the highest correlation coefficients, being strongly correlated with dental wear and less correlated with each other. In conclusion, F1 and F5 factors were independent and represented the main cause of dental wear investigated in this study. The impact of these factors on erosive dental wear was determined by their association with the dental wear score.

The biggest impact was caused by energy drinks, yoghurt and carbonated beverages. Through the 
associations resulting from factorial analysis, the mechanisms involved in the erosive dental wear were also highlighted, the first place was taken by biocorrosion, followed by friction and stress.

Acknowledgement: The study was part of a research project Development of a dental wear monitoring and prediction system for children aged between 6 and 14 years (No. 638/23.05.2017) carried out during 2017-2020 financed by the Romanian Society for Research in Dental Medicine.

\section{References}

1.EGLE MICKEVICIUTE, AUSRA BALTRUSAITYTE, GAIVILE PILEICIKIENE. The relationship between pathological wear of teeth and temporomandibular joint dysfunction. Stomatologija, Baltic Dental and Maxillofacial Journal, 2017, Vol. 19, No. 1, 1-7.

2.J.O. GRIPPO, M. SIMRING, S. SCHREINER. Attrition, abrasion, corrosion and abfraction revisited. A new perspective on tooth surface lesions. Journal of the American Dental Association, 135(8), 2004, 1109-1118.

3.MOROZOVA, YULIYA \& HOLIK, PAVEL \& CTVRTLIK, RADIM \& TOMASTIK, JAN \& FOLTASOVA, LENKA \& HARCEKOVA, ANNAMARIA. (2016). Tooth Wear-Fundamental Mechanisms And Diagnosis. IOSR Journal of Dental and Medical Sciences. 15. 84-91. 10.9790/08531505088491.

4.V. MERCUT, S.M. POPESCU, M. SCRIECIU, M.O. AMARASCU, M. VATU, O.A. DIACONU, E. OSIAC, M. GHELASE. Optical coherence tomography applications in tooth wear diagnosis. Rom J Morphol Embryol 2017, 58(1):99-106.

5.ADDY M. and SHELISS R.P. Interaction between attrition, abrasion and erosion in tooth wear. Monographs in Oral Sciences, 20, 2006, 17-31.

6.BARTLETT DW, SMITH BG.. Etiology and management of tooth wear: the association of drugs and medicaments. Drugs Today (Barc). 1998. Mar; 34(3):231-9.

7.A. LUSSI, C. GANSS, Erosive tooth wear from diagnosis to therapy (Basel: Karger, 2014).

8.CARVALHO T.S., COLON P., GANSS C., HUYSMANS M.C., LUSSI A., SCHLUETER N., SCHMALZ G., SHELISS P.R., TVEIT A.B., WIEGAND A. Consensus report of the European Federation of Conservative Dentistry: Erosive tooth wear-diagnosis and management. Clin. Oral Investig. 2015;19:1557-1561.

9.SALAS MM, NASCIMENTO GG, HUYSMANS MC, DEMARCO FF. Estimated prevalence of erosive tooth wear in permanent teeth of children and adolescents: an epidemiological systematic review and meta-regression analysis. J Dent 2015;43:42-50.

10.LOOMANS B, OPDAM N, ATTIN T, BARTLETT D, EDELHOFF D, FRANKENBERGER R, BENIC G, RAMSEYER S, WETSELAAR P, STERENBORG B, HICKEL R, PALLENSEN U, MEHTA S, BANERJI S, LUSSI A, WILSON N. Severe Tooth Wear: European Consensus Statement on Management Guidelines. J Adhes Dent. 2017;19(2):111119.

11.MANAL AL HALABI, SHAIMA AL KAYOUMI, AMAR H. KHAMIS, SAMI CHOGLE. Prevalence of Tooth Wear in Primary Dentition in School Children of Abu Dhabi, UAE. Applied Clinical Research, Clinical Trials and Regulatory Affairs.Vol.3,Iss. 1,2016, 27-33.

12.CARVALHO TS, LUSSI A, JAEGGI T, GAMBON DL. Erosive tooth wear in children. Monogr Oral Sci. 2014;25:262-78.

13.HUNTER ML, WEST NX, HUGHES JA, NEWCOMBE RG, ADDY $M$. Erosion of deciduous and permanent dental hard tissue in the oral environment. Journal of dentistry. 2000; 28:257-63.

14.KREULEN CM, VAN'T SPIJKER A, RODRIGUEZ J M, BRONKHORST EM, CREUGERS NH, BARTLETT DW. Systematic review of the prevalence of tooth wear in children and adolescents. Caries research. 2010; 44:151-9.

15.LUSSI A, SCHLUETER N, RAKHMATULLINA E, GANSS C. Dental erosion-an overview with emphasis on chemical and histopathological aspects. Caries research. 2011; 45 Suppl 1:2-12.
16.SHELLIS RP, GANSS C, REN Y, ZERO DT, LUSSI A. Methodology and models in erosion research: discussion and conclusions. Caries research. 2011; 45 Suppl 1:69-77.

17.0'SULLIVAN EA, CURZON ME. A comparison of acidic dietary factors in children with and without dental erosion. ASDC J Dent Child. 2000; 67:186-92, 60.

18.HUNTER ML, PATEL R, LOYN T, MORGAN MZ, FAIRCHILD R, REES JS. The effect of dilution on the in vitro erosive potential of a range of dilutable fruit drinks. International journal of paediatric dentistry/the British Paedodontic Society [and] the International Association of Dentistry for Children. 2008; 18:251-5.

19.LUSSI A, MEGERT B, SHELLIS RP, WANG X. Analysis of the erosive effect of different dietary substances and medications. $\mathrm{Br}$ J Nutr. 2012; 107:252-62.

20.SHELLIS RP, BARBOUR ME, JESANI A, LUSSI A. Effects of Buffering Properties and Undissociated Acid Concentration on Dissolution of Dental Enamel in Relation to $\mathrm{pH}$ and Acid Type. Caries research. 2013; 47 (6):601-11.

21.LUSSI A, CARVALHO TS. Analyses of the Erosive Effect of Dietary Substances and Medications on Deciduous Teeth. 2015. PLoS ONE, 10(12): e0143957.

22.RADLANSKI RJ, RENZ H, WILLERSINN U, CORDIS CA, DUSCHNER $H$. Outline and arrangement of enamel rods in human deciduous and permanent enamel. 3D-reconstructions obtained from CLSM and SEM images based on serial ground sections. Eur J Oral Sci. 2001; 109(6):409-14.

23.GANSS C, KLIMEK J, GIESE K. Dental erosion in children and adolescents - a cross-sectional and longitudinal investigation using study models. Community Dent Oral Epidemiol. 2001; 29 (4):264-271. 24.HARDING MA, WHELTON HP, SHIRODARIA SC, O'MULLANE DM, CRONIN MS. Is tooth wear in the primary dentition predictive of tooth wear in the permanent dentition? Report from a longitudinal study. Community Dent Health. 2010; 27(1):41-5.

25.AL-MAJED I, MAGUIRE A, MURRAY JJ. Risk factors for dental erosion in 5-6 year old and 12-14 year old boys in Saudi Arabia. Community Dent Oral Epidemiol 2002;30:38-46.

26.P. WANG, H.C. LIN, J.H. CHEN, H.Y. LIANG, The prevalence of dental erosion and associated risk factors in 12-13-year-old school children in Southern China, BMC Public Health, 2010, vol. 10, article 478.

27.J ARVINEN V.K, RYTOMAA I.I, HEINONEN O.P. Risk factors in dental erosion. J ournal of Dental Research. 1991; 70(6):942-947.

28. HUEW R, WATERHOUSE P, MOYNIHAN P, KOMETA S, MAGUIRE A. Dental caries and its association with diet and dental erosion in Libyan schoolchildren. Int J Paediatr Dent. 2012; 22(1):68-76.

29.KUMAR S, ACHARYA S, MISHRA P, DEBNATH N, VASTHARE R. Prevalence and risk factors for dental erosion among 11- to 14-yearold school children in South India.J Oral Sci. 2013;55(4):329-36.

30.CHIRIAC A.M, MERCU V, ALEXANDRU D, POPESCU M.S, DASCÃLU I, MANOLEA O.H, RESCEANU I. Epidemiological study of dental wear in children between 6 and 11 years old from Dolj County, Romania. Romanian J ournal of Oral Rehabilitation, 2018,Vol. 10, No.4, 20-28. 31.REDDY, AVANIJA \& F. NORRIS, DON \& MOMENI, STEPHANIE \& WALDO, BELINDA \& RUBY, JOHN. The pH of beverages in the United States. The Journal of the American Dental Association. 2015. 147. 10.1016/j.adaj.2015.10.019.

32.ARMSTRONG J.S. Derivation of theory by means of factor analysis or Tom Swift and his electric factor analysis machine. The American Statistician, (1967), 21 (1), 17-21.

33.HOGARTY K.Y. The Quality of Factor Solutions in Exploratory Factor Analysis: The Influence of Sample Size, Communality, and Overdetermination. Educational and Psychological Measurement, 65, 2005, (2), 202-226.

34.ADRIAN LUSSI, DDS, MS, ELMAR HELLWIG, DDS, DOMENICK ZERO, DDS, MS, \& THOMAS JAEGGI, DDS. Erosive tooth wear: Diagnosis, risk factors and prevention. 2016.

35.LUSSI A, JAEGGI T. Extrinsic causes of erosion. Chemical factors. In: Lussi A. Dental erosion: From diagnosis to therapy. Basel: Karger: 2006, 77-87. 
36.LUO A, ZENG XJ, DU MQ, BEDI R. The prevalence of dental erosion in preschool children in China. J Dent. 2005; 33:115-121.

37.HARDING MA, WHELTON H, O'MULLANE DM, CRONIN M. Dental erosion in 5-year-old Irish school children and associated factors: a pilot study. Community Dent Health 2003;20:165-170.

38.J OHANSSON AK, SORVARI R, BIRKHED D, MEURMAN JH. Dental erosion in deciduous teeth-an in vivo and in vitro study. J Dent 2001;29:333-340.

39.LUSSI A, JAEGGI T, ZERO D. The role of diet in the aetiology of dental erosion. Caries Res 2004; 38 Suppl 1:34-44.

40.LUSSI A, SCHAFFNER M, HOTZ P, SUTER P: Dental erosion in a population of Swiss adults. Community Dent Oral Epidemiol 1991, 19(5):286-290.

41.LUSSI A, CARVALHO TS. Erosive tooth wear: a multifactorial condition of growing concern and increasing knowledge. Erosive Tooth Wear. 25: Karger Publishers;2014.p.1-15.

42.BARTLETT D, LUSSI A, WEST N, BOUCHARD P, SANZ M, BOURGEOIS $D$. Prevalence of tooth wear on buccal and lingual surfaces and possible risk factors in young European adults. Journal of dentistry. 2013;41(11):1007-13.

43.GIUNTA JL. Dental erosion resulting from chewable vitamin C tablets. The Journal of the American Dental Association. 1983;107(2) :253-56.

44.R.M. FAIRCHILD, D. BROUGHTON \& M.Z. MORGAN. Knowledge of and attitudes to sports drinks of adolescents living in South Wales, UK. BDJ, volume 222, pages 931-935 (23 J une 2017).

45.GAMBON DL, BRAND HS, BOUTKABOUT C, LEVIE D, VEERMAN EC. Patterns in consumption of potentially erosive beverages among adolescent school children in the Netherlands. Int Dent J. 2011. Oct; 61(5):247-51.

46.LUSSI A, CARVALHO TS. Analyses of the Erosive Effect of Dietary Substances and Medications on Deciduous Teeth. PLoS One. 2015 Dec 23; 10(12):e0143957.

47.J ING ZHANG, YANGGE DU, ZHAO WEI, BAOJ UN TAI, HAN J IANG and MINQUAN DU. The prevalence and risk indicators of tooth wear in 12and 15-year-old adolescents in Central China. BMC Oral Health. 2015; 15: 120.

48.J IANG H, DU MQ, HUANG W, PENG B, BIAN Z, TAI BJ . The prevalence and risk factors of non-carious cervical lesions in adults in Hubei Province, China. Community Dent Health. 2011;28(1):22-8.

49.CLAUDIA RESTREPO, DANIELE MANFREDINI, RUBEN MANRIQUE and FRANK LOBBEZOO. Association of dietary habits and parental reported sleep tooth grinding with tooth wear in children with mixed dentition. BMC Oral Health, 20 December 2017.

50.HEIKKINEN T, RUSANEN J, HARILA V, ALVESAVO L. Primary tooth wear in functional lateralities. J Dent Child (Chic). 2009;76:5-12.

51.TSIGGOS N., TORTOPIDIS D., HATZIKYRIAKOS A., MENEXES G. Association between self-reported bruxism activity and occurrence of dental attrition, abfraction, and occlusal pits on natural teeth. J. Prosthet. Dent. 2008, 100, 41-46.
52.OKURA K., SHIGEMOTO S., SUZUKI Y., NOGUCHI N., OMOTO K., ABE S., MATUSKA Y. Mandibular movement during sleep bruxism associated with current tooth attrition. J. Prosthodont. Res. 2017, 61, 87-95.

53.K. VENKAIAH, G.N.V. BRAHMAM, K. VIJ AYARAGHAVAN. Application of Factor Analysis to Identify Dietary Patterns and Use of Factor Scores to Study Their Relationship with Nutritional Status of Adult Rural Populations. J Health Popul Nutr. 2011 Aug; 29(4): 327-338.

54.C.H. CHU, K.K.L. PANG, E.C.M. LO. Dietary behavior and knowledge of dental erosion among Chinese adults. BMC Oral Health, vol. 10, no. 1, article 13, 2010.

55.AGUIAR YP, SANTOS FG, MOURA EF, AUAD SM, DE PAIVA SM et al. Association between dental erosion and diet in Brazilian adolescents aged from 15 to 19: a population-based study. The Scientific World Journal. 2014; 2014:818167.

56.0'SULLIVAN EA, CURZON ME: A comparison of acidic dietary factors in children with and without dental erosion. ASDC J Dent Child 2000, 67(3):186-192, 160.

57.GRADINARU, I., IGNAT, L., DASCALU, C.G., SOROAGA, L.V., ANTOHE, M.E., Studies regarding the architectural design of various composites and nanofibres used in dental medicine, Rev. Chim. (Bucharest), 69, no. 2,2018, p.328-331

58.ASAFTEI, I.V, SANDU,I.G., MIHAIL,L,ET AL, Conversion of industrial fedstock mainly with butanes and butenes over B-HZSM-5 and ZnHZSM-5 modifed catalysts, Rev. Chim. (Bucharest), 66, no. 3,2015, p.336-341

59.ANTOHE, M.E., FORNA AGOP, D., DASCALU, C.G., FORNA, N.C., Implications of digital image processing in the paraclinical assessment of the partially edentated patient, Rev. Chim. (Bucharest), 69, no. 2, 2018, p.521-524

60.MATEI, M.N., EARAR, K., TRINCA, L.C., Degradation characteristics of poly-tetrafluoroethylene coatings on stainlesssteel orthodontic wires immersed in tuna fish derived products, Rev.Chim.(Bucharest), 67, no.4, 2016, p.800-807

61. MATEI , M.N., CHISCOP, I., EARAR, K., et al., Evaluation of corrosion resistance of $\mathrm{NiTi} \mathrm{Nb}$ orthodontic wires in tomato juice, Rev.Chim.(Bucharest), 66, no.12, 2015, p.2009-2012

62. MARECI, D., EARAR, K., ZETU, I., Comparative electrochemical behaviour, of uncoated and coated $\mathrm{Ni} \mathrm{Ti}$, for dental orthodontic wires, Rev. Chim.(Bucharest), 52, no.2, 2015, p, 150-153

63.ANCUTA ,C., POMIRLEANU, C., IORDACHE,C., ET AL., Serum lipid profile in diffuse versus limited systemic sclerosis data from the SASS cohort, Rev. Chim.(Bucharest), 69, no.2, 2018, p.403-406

64.BUDACU, C., NEMTOI, A., CONSTANTIN, M., Biomaterials used in Reduction and Fixation of Unstable Fractures of the Zygomaticomaxillary Complex, Mat.Plast., 54, no.4, 2017, p.773-776 65.NITESCU, D., MIHAI, C., OANTA, C., Evaluation of Cumulative Effects of Chemotherapy and Bevacizumab (Avastin) in Oncological Patients with Periodontal Disease, Rev. Chim.(Bucharest), 68, no.3, 2017, p. 549

66.NICULESCU,O., NICA ,P., GURLUI, S., et al., Experimental Investigations of Polymer Plasma Laser Ablation, Mat.Plast.,46, no.3, 2009, p. 336-338

$\overline{\text { Manuscript received: } 19.07 .2018}$ 